\title{
LAWSUITS AND POLITICAL PSYCHOLOGY APPLIED TO IDEOLOGICAL THREATS AGAINST PEACEFUL ORGANIZATIONS AND AGREEMENTS
}

\author{
Pierangelo Sardi*
}

The agreement between US and China on climate change, announced on November 12, 2014, should not create so many problems as an apparently similar agreement signed between the Member States of the European Union the 24th of October. Problems not only exist in the legal domain, but possibly in much worse frames, if we look to a worrying precedent, now deserving further psychological analyses. During the twenties of the previous century Italy invented Fascism-an ideology generating conflict that the Society of Nations intended to prevent. A decade later, Germany turned this Italian invention into Nazism. Both countries renounced peaceful, agreed sources of energy: Italy bartering its rights on Iraqi oil with tacit consent to attack Abyssinia (modern-day Ethiopia); Germany chasing the Jewish scientists who were able to provide what later was called "atoms for peace". The need for energy became a desperate addiction for both countries, halted militarily at the River Don and El Alamein while trying to reach Caspian and Middle Eastern wells. Now, European construction, started in 1957 on the basis of fair and peaceful access to energy guaranteed by the parallel Euratom treaty, is in jeopardy. Italy in the eighties, after Chernobyl, and also Germany now, after Fukushima, rejected the source of energy their manufactures would need, without considering the data and diagrams clearly related to these irrational choices: the appropriate application of political psychology can prevent these countries from repeating their past mistakes while dealing with energy sources.

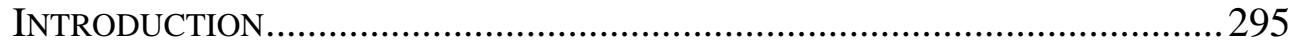

I. INTERESTING WORK FOR LAWYERS ................................................ 298

II. Political Psychology and CRises of PeACEFul ORganizations ...301

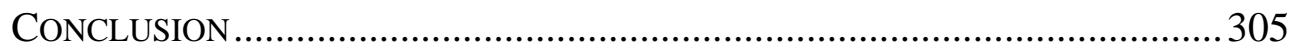

\section{INTRODUCTION}

Following their recent agreement on climate change, the governments of US and China will have to respect the stated limits, but still maintain their

\footnotetext{
${ }^{*}$ Formerly scholar of Work and Organisation Psychology, chair of the Italian Chamber of Psychologists www.psy.it and of the European Council of Liberal Professions www.ceplis.eu, is currently co-president of the Association of Psychologists of Italian Origin in the World, as such organizing the European Congress of Psychology 2015 www.ecp2015.it. Research fields: Road Risks, Psychological Aid in Disaster and Crises, Irrational Economic Choices.
} 
freedom to choose the source of their energy provision, and both their presidents have not at all excluded to reduce green-house gas emissions by widening their own country's nuclear production. This agreement should not create much work for lawyers competent in this field, which should better draw their attention from the Pacific Ocean to beyond the Atlantic until Europe: A long series of lawsuits could derive from the agreement formally signed by the heads of the 28 member states of the European Council a few weeks before. Indeed, they have adopted a very divergent track on this aspect, dividing themselves into two opposite groups. This energy divide is going to follow the different clauses regarding the greenhouse gas emissions' reduction, on one side, and the increase of the renewable sources, on the other side.

On the first side the emissions, essentially depending from the fossil sources, must be reduced nationally: country by country. This clause will further compress the fossil-addict economies, requiring terrible sacrifices to this group. Ireland implored and obtained a slight discount in order not to slaughter all its methane-belching cows ${ }^{1}$. This jugular clause is not weighing on the countries limiting enough their emissions through nuclear energy production.

On the contrary, the mandatory target of a higher percentage of renewable sources is not weighing on each and every country, but on the whole group. The countries of the above mentioned lucky group can contribute even by $0 \%$, while the other ones must contribute by until $40 \%$ or more, insofar they do not succeed in reducing enough their fossil fuel emissions. This will create further problems to these economies who are already most shaky, together with the intermittence of their renewable sources: Portugal is planning a huge electro-duct across all the Iberian peninsula, till beyond the Pyrenees, in order to compensate its terrific oscillations and lacks of electricity thanks to the integrations by French nuclear production.

As an EU-funded advertisement boasts after this agreement, the same charity is already provided by France across the Alps to Italy: quite a relevant case study, since this country decommissioned its nuclear plants at the beginning of the nineties, a unique case among the G20 members, and the only mainly manufacturing country of all over the world, having decided this rejection.

Italian industries thus arrived to pay the electricity nearly five times the cost of French industries, \$29 cents to 6 per Kwh as lastly calculated by EIA,

\footnotetext{
${ }^{1}$ This piteous clause is mentioned as such by http://www.economist.com/news/europe/21629387climate-change-if-little-else-europe-still-aspires-global-leadership-environmental.
} 
the Energy Information Administration of the US government ${ }^{2}$. The gap between the two costs will increase in proportion with the increase of the gap between the two diverging percentages of renewable production. Italy paid 13 billion last year for its renewables, just in order to get from them the electricity costing in Italy 3 billion. Considering the already dearer cost of electricity for Italian industries, the new portion of renewables due to be acquired by Italy will cost around 20 times that of the French electricity for industries; this cost not needing to be raised, as explained above.

This will increase the flow of Italian work towards France, already the first target country of migration, above all the rest of world, as counted by the CGIA, the Italian Chamber of Commerce since the year $2000^{3}$. A flow strictly proportioned to the cost of the Kwh, if we just compare the two last quoted statistics, in footnotes 3 and 4 respectively. While the Italian Kwh costs to Italian firms 29 cents (world record), France, with its 6 cents per Kwh, has attracted 2.562 Italian firms, again world record. France is followed, in such and order of attraction, by the USA ( 7 cents and 2.409 firms), Germany (11 cents and 2.099 firms), Spain (12.5 cents and 1.925 firms), and United Kingdom (15.5 cents and 1.856 firms). The co-variance is rigorous even in the correspondence of the respective distances, of migrations on one side, and of the differences between the costs of electricity on the other side: only 1 cent between France and USA, and only 154 firms of difference; a higher difference between USA and Germany in electricity costs (4 cents) and the different move raises to 309 firms. Again lower the gap between Germany and Spain (1.5 cents) and again is lower the shove to de-localisation: 174 firms. Even half a cent has its relevance, as we see in the difference between France and USA on one side (1 cent and 154 firms), Germany and Spain on the other side (1.5 cent and 174 firms).

And the flow directly changes along the years in proportion with the changes in nuclear energy production. The move of firms is not so updated by EIA and CGIA, but Italian skilled workers enormously increased their migration to the previously last ranged country, UK, after the announcements of its intent to reach the $80 \%$ of nuclear production of its electricity, above the $75 \%$ of France. The current French authorities, on the contrary, declared their intention to reduce this percentage to $50 \%$, and now even to 25\%. Growing promises, but not accompanied by any practical action. Namely, the decommissioning of the oldest nuclear plant, at Fessenheim in Alsace, promised by president Hollande to be implemented

\footnotetext{
${ }^{2}$ http://www.eia.gov/countries/prices/electricity_industry.cfm.

${ }^{3}$ http://www.dazebaonews.it/economia/item/17490-cgia-delocalizzazione-in-italia-27mila-impresesono-fuggite-ecco-i-numeri.
} 
by 2016, and requiring at least 4 or 5 years, has not yet started at all; the prestigious Le Monde explicitly doubts it will be done, considering the invitation by Ms Ségolène Royale, the Minister of Ecology, to reconsider the convenience of this promise of her former husband. Anyhow, polls say that the next ballot for presidency will be disputed between Mr Sarkozy and Ms Le Pen, both pro-nuclear. The official declarations of the current French authorities could look to Italians as what they call gioco delle tre carte, a popular way to induce the cheated person to grant money to the cheater. Understanding why Italians still believe to these promises should be a competence of political psychology: This discipline will be involved later, after a chapter devoted to legal issues.

This flow towards USA is perfectly legal, insofar the US, though proposing "Atoms for Peace" from the Eisenhower presidency, did not sign the Euratom Treaty in 1957, which still binds all the 28 member states of the present EU "to develop a powerful nuclear industry" just in order to avoid such a dangerous divide. If not yet the common sense of all the European populations, this superior Treaty makes clearly and simply illegal all the sort of agreements exemplified above.

\section{INTERESTING WORK FOR LAWYERS}

The Euratom Treaty, signed together with the Rome Treaty and subscribed also by each and every new entry in the European construction, is still perfectly in force, with just an abrogation of its article 3: The parallel provisions foreseen in that article are now absorbed by the corresponding three European bodies: Council, Parliament, and Commission.

During the first years of implementation of the European construction, economists were suggesting four criteria to be reached before arriving to a common currency like the Euro has later become": "1.) labor mobility across the region; 2.) openness with capital mobility, price and wage flexibility across the region; 3.) a risk sharing system; 4.) the participant countries have the same business cycles."

The problem is that, while the two first criteria have been correctly implemented in some decades, the EU bodies and especially the Commission did exactly the contrary of what the Euraton Treaty established, and still requires, in order to implement the last two criteria, and especially

\footnotetext{
${ }^{4}$ Quoted from: Ronald I. McKinnon, Optimum Currency Areas, 53(4) The AmERICAN ECONOMIC REVIEW 717-725 (1963), quoted also by Jànos Kàlmàn, Toward the European Federation? 10(1) THE AMERICAN ECONOMIC REVIEW 46-67 (February 2013), where the European construction's financial stability is severely questioned.
} 
the last one, through a totally diverging energy policy. Namely, the Euro has been launched just a decade after the second biggest European manufacturer, Italy, had phased out its nuclear plants by the first referendum.

But how could that first and later a second referendum allow Italy to infringe the obligations imposed by the Euratom treaty? This objection is doubled by Article 75 of the Italian Constitution, which impedes to modify any International Treaty by referendum. The answer is easy to explain, though difficult to believe: Both the referenda did not at all cancel the nuclear energy policy implemented in respect of the Euratom treaty by the Italian authorities twice, that is, before both those referenda. The first referendum was abrogating the authorization to built nuclear plants just abroad; the second one was even in favour of the Italian nuclear policy, insofar it firstly abrogated the one year's suspension of the re-launch of the national nuclear program, and secondly it abrogated the duty to consult local populations before placing any kind of plant in their territory.

We will see in the next chapter how psychologists could explain such a distorted perception.

Meanwhile, let's consider how many legitimate interests could pursue the illegitimate interpretation of those referenda in Italy, and their subsequent actions. Many thousands of firms did not dare to migrate abroad: they simply failed; many are still failing now, and many more will fail soon after the above described agreement of the 24th of October. Their workers can start various class actions against the authorities illegally forcing them to migrate or starve.

But even the European Commission is responsible for this divide. The IEA, International Energy Agency, an OECD body based in Paris, has published in 2008 a book ${ }^{5}$ reviewing the energy policy of the EU. At page 27 this review, based on a visit to the EU Commission, states that:

Acknowledging the sensitivities regarding some aspects of energy policy in member states, EU energy policy actions have respected, and will continue to respect, two principles: first, that member states are ultimately responsible for their national energy mix; and secondly, that indigenous energy resources are a national, not European, resource.

Indeed, it would be difficult to change the "sensitivities" of Norwegian or Scottish people who consider their hydrocarbons as "indigenous energy resources", nor is this a scope of the Euratom Treaty; but it is possible, and

\footnotetext{
${ }^{5}$ Available at http://www.iea.org/publications/freepublications/publication/eu2008.pdf.
} 
also a scope of the treaties founding the European construction ${ }^{6}$, not to increase such a sensitivity about the capacity to make "indigenous" choices in energy sources counter-posed to those of the other member states. These subjective social attitudes, not even after having been ratified by apparently democratic referenda, should not be left included under this meaning of objective "energy resources".

Even worse, the Commission has actively promoted this divide, exactly opposite to the equalizing scope of the Euratom treaty. Various EU-funded projects have been devoted to improve the interaction between the nuclear plants and the societies surrounding them, e.g.: PLATENSO ${ }^{7}, \mathrm{COWAM}^{8}$, ARGONA $^{9}$, IPPA ${ }^{10}$, PIPNA ${ }^{11}$ etc. usually involving a wide number of more or less organised parts of those civil societies, from their geographical vicinity up to national level, but never beyond the borders of the pro-nuclear group of countries. No one of these projects has been effective in contrasting the two divergent trends found by Eurobarometer ${ }^{12}$ : "citizens in countries that have operational nuclear power plants are considerably more likely to support nuclear energy than citizens in other countries.” When an Italian State agency drafted a project answering to the call NFRP $12^{13}$, in order to survey the origin of the opposed attitudes towards nuclear energy in the two groups of countries, the Commission did not answer to a question posed nearly two months before the deadline until the day before it; this delayed answer of the Commission imposed to modify all the agreements of that consortium in just 8 and 3/4 of working hours' time. That's obviously impossible. On the contrary, the Commission systematically devotes the Euratom money in generously funding the Italian proposals (firstly IGNITOR and now ITER) aiming at the long-delayed dream of the fusion process, so diverting the technical ambitions of these professionals away from the currently efficient fission activity.

The European Court of Justice, when asked about the persistence of the

\footnotetext{
${ }^{6}$ Even if it is stated, at the beginning of that same page 27, that "there is currently no specific article on energy in the currently ratified EU treaties". On the contrary, the Euratom treaty is still in force, and binding any member state.

${ }^{7}$ http://www.karita.se/docs/SKI_Report_2004_08.pdf.

${ }^{8}$ Funded in various phases: COWAM, COWAM 2 and COWAM in Practice; all related reports are available on the COWAM website: http://www.cowam.com.

${ }^{9} \mathrm{http}: / /$ www.argonaproject.eu.

${ }^{10} \mathrm{http}: / / \mathrm{www}$.ippaproject.eu.

${ }^{11} \mathrm{http}: / / w w w . m u t a d i s . o r g / i n d e x . p h p / e n-c o u r s / 134-p i p n a$.

${ }^{12}$ Quoted from page 6 of the Eurobarometer report http://ec.europa.eu/public_opinion/archives/ebs/ebs_297_en.pdf.

${ }^{13} \mathrm{http}$ ://ec.europa.eu/research/participants/portal/desktop/en/opportunities/h2020/topics/2315-nfrp12-2015.html.
} 
Euratom Treaty by Austria, against the nuclear plant activated by the Czech Republic in Temelin, near the Austrian border, gave a positive sentence, in favor of the plant. The same Court could be worried about the distorted interpretations and infringements of the Euratom Treaty, causing such a dangerous divide in the European construction, prone to collapse as the former League of Nations did. But the similarities between the two collapses require to pass into another discipline, from jurists to psychologists.

\section{Political Psychology and CRises of PeAceful ORganizations}

A desperate destiny of energy-addiction is currently accepted, agreed, and even searched, by a group of European countries, led initially by Italy and later by Germany. It is not the first time that such a psychopathology invests these two populations after their passage from recent re-unifications to new leading roles.

For many people, like the Italian one, to remain in the European Union is becoming increasingly disastrous, but if it would be even more disastrous to get out, then maybe it's worth to submit to the unpleasant psychological analysis of the cause of this disaster, which is not comparable to any of the other economic crises; you can only compare it to a war, disastrous and loser, yet with no way out better than the defeat, even more disastrous.

Individuals do not undergo psychological analysis except when they are really desperate, never for the simple interest to live better. In fact, we all postpone any other interest to the strange advantage of keeping well repressed in our unconscious what we have removed. In this irrational choice both families, groups, whole populations do not behave differently from individuals, as had already been described by Freud in 1921 with "Group Psychology and the Analysis of the Ego".

In order to arrive at a psychological diagnosis, it is not enough to collect a description of symptoms, which is usually partial: The involved person tends to hide always the most important, the most active one. It is better to start from an anamnesis: The description of what happened a long time before becomes less contrasted when the explanation of what had gone wrong has received enough masks that make it unrecognizable in its repetition (the Freudian Wiederholung). Even if the person concerned considers and defines those mishaps like water already passed, the psychologist who collects the anamnesis assumes the exact opposite: $\mathrm{He}$ considers that water still grinding, and sees in the current trouble a compulsion to structurally repeat just what went wrong beforehand. The 
greatest apparent differences mislead all but the analyst, who knows how to extract from them, how to isolate a single trait: ein enziger zug, Freud said, le trait unaire, Lacan translated since his seminar of 1960/61 on the identification, unary trait in Lacanian English. Hidden but essential, because this absolute simplification, the uniqueness of that viral element enables a whole group, an entire population to identify itself, not just to a leader, not needed as a whole, but in a particular trait of which he is a carrier. Just like a virus, such as that of HIV, in order to explode can have used a young, attractive assistant on international flights, but also freer sexual mores in that period among the homosexuals, the heterosexuals, the drug addicts, or transfusions, any other infection, in our case we say better: every communication.

While democracies are institutionally considered to safeguard pluralism or at least the dualism by the opposition to the majority, in order to rightly oppose the dangerous tendency to identification's oneness, the political psychology has always detected even in democracies a popular trend to the restriction of the options with respect to usual determinants for other judgments given on each other, not only less than the classic ten basic values, but even less than the big five (extroversion, agreeableness, conscientiousness, stability, openness) ${ }^{14}$ : When the situation slips into the pathology, the minority becomes frustrated, and even the choice of the majority narrows until the unary trait that plagues the entire people.

Searching for that einziger zug, that symptomatic trait among the group of European nations in their history in order to understand how and when has been wasted something similar to the current European construction, we cannot look to the UN, where Europe counts for little; rather it is easy to see how a well-defined dynamics of a couple of European countries has destroyed a construction that initially seemed equally praiseworthy, also potentially destined to win the Nobel Peace Prize: It was called the Society or the League of Nations.

The construction of Europe, founded in 1957 after the signing of the Treaty of Rome and the contextual Euratom, is crumbling: It is a duty of psychologists to investigate whether this happens again under the initiative of the same member countries that had already undermined the construction of the League of Nations. If it must be a repetition, we should see that Italy starts, and then comes Germany which, despite being second in the same disruptive initiative, proves much more efficient both times in the same destructive action.

\footnotetext{
${ }^{14}$ see e.g. Gianvittorio Caprara, in TEMPI ModERni (MODERN TIMES, Giunti 2008), especially at 226, where he recognizes the tendency not to admit more than two options.
} 
The duration of the League of Nations was shorter than that of the current construction of Europe: Italy invented Fascism, fanning an exasperated nationalistic selfishness that clashed with the peaceful cooperation of nations in the League. It is not fascism that threatens to repeat today those same slogans, from which Europe is largely immunized; but we should pay attention: It was not fascism as a whole to break then the League of Nations; more precisely, it was not at all an exasperation of the national interest. Not at all: leaving apart illusions, it was just the contrary.

Towards the rupture moved Italy when Mussolini, instead of profiting from Italian rights on the Middle East oil, which were consistent and also accepted by the UK, abruptly preferred to barter them with a benevolent tolerance toward the invasion of Ethiopia, in open violation against the rules of the League of Nations, of which Ethiopia was a member. In vain the president of AGIP, Mr Ottieri, attempted to demonstrate to the Duce his dismay at this barter, so inconvenient for Italy and for peace; Mussolini prevented any objection: "The highest destinies of our country require us to sacrifice our oil interests in Iraq... I demand the utmost obedience and command you to follow the rules... remember that the fate of the Fatherland is in play”" ${ }^{\prime 15}$. Until that speech, Italy had been pursuing exactly the policy which will be of Enrico Mattei: respectful towards the rights of the people having that oil beneath their feet, therefore welcome by those populations. Without that barter of Mussolini with the UK, Italy in the 30s could have already profited from the same excellent condition that Enrico Mattei translated, after the second, unnecessary world war, in the Italian economic miracle. Two opposite kinds of "heroic imagination", as Philip Zimbardo calls it, have been represented by Mussolini and Mattei, the bad one apparently much more able to involve the enthusiasm of the crowds into its ruinous trend, as today the enormous (not only economic) sufferance caused by the anti-nuclear movement remains compatible with the crowds applauding its self-defining "green" leaders.

So the demagogy of the Fascist regime had become able to undermine the autonomy in the national energy flow. With that purely populist choice, fascist Italy ultimately triggered the violent infraction of the rules of the League of Nations not only because Ethiopia was a member but, much more important, because, self-condemning to a dependence from energy sources of others, it self-condemned also to increase its aggressiveness for raping them, just as we can see at any crime derived from addiction ${ }^{16}$.

Germany has only exasperated the same dynamic, proving more

\footnotetext{
${ }^{15}$ Reported by Cereghino and Fasanella, "Il Golpe Inglese”, CHIARELETTERE 31-36 (2011).

${ }^{16}$ See also http://rivista.ssef.it/site.php?page=20060206145323894.
} 
determined than Italy in self-condemning to depend from the energy of others: It was Hitler's Germany to expel those Jewish scientists who were clearly finding the best solution to energy needs in the nuclear source, infinitely better than tear out petrol from coal, or desperately trying to reach it warring beyond the Don until the Caspian Sea, or beyond El Alamein until the Middle East.

The Nazis officially banned the practice and theories of Einstein, who promised to get huge amounts of energy from small amounts of mass. It seems easy to say that Einstein was banned simply because he was a Jew, considering the hatred of Jews a symptom of the madness of Hitler and as such inexplicable. In the psychological analysis, instead, the irrationality of the symptoms becomes more understandable, in the individual as well as in the peoples. The charity Hitler personally received from the free canteens offered by wealthy Jews during his miserable adolescence in Austria, through the destructive envy of the nutritious breast, masterfully described by Melanie Klein, explains much of his subsequent aggression toward Jews. Hitler was invaded by a syndrome already studied by psychologists: orthorexia, a variant of anorexia, which prevents the patient from eating certain foods, though vital. Even when he was a guest at the richest dinners of the Italian authorities in his official visit, Hitler refused everything, eating only chocolate bars, which strove to cut with a knife and put in his mouth with a fork.

This pathological character trait, transferred from the food to the miraculous cornucopia of the nascent German industry, can easily have infected the whole German people, facing the generosity of the miraculous new source of energy Einstein was envisaging and offering. In psychoanalysis, the effect is never considered as an unintended fallout of the cause: It is always better to consider it as directly causing the cause itself. The loss or even the active refusal of the invention offered by Einstein was the real cause, indeed, the objective precisely pursued in the extermination of Jews by the Nazis. The fact is that, even with their so-called "Aryan" colleagues who remained in Germany, funds were strangled: as Georgio Prinzi has shown in its commemoration of the atomic pile invention by Fermi ${ }^{17}$, the reactor those German researchers managed to build, biking up to the cave under the church at the top of Heigerloch, was simply too small to become critical. Thus demonstrating, mathematically, the Nazi stubbornness in wanting to force Germany into dependence from a quantity of hydrocarbons initially unreachable peacefully, therefore belligerently,

\footnotetext{
${ }^{17}$ See http://www.giorgioprinzi.it/nucleare/audiovisivifonti/enricofermi.pdf p. 25.
} 
until the final disaster.

The Italian nuclear research had been going on too much more than the German one to be choked only with some cuts in funding. Even Italian funds were hastily curtailed, with the preposition of a general to $\mathrm{CNR}^{18}$, also ominously imposed. But, in order to discourage Enrico Fermi from implementing its atomic pile, i.e., the first nuclear-fission reactor, it was necessary to threaten and hit that scientist in his family affections.

Decisive was the celebration ceremony for the award of the Nobel Prize, staged at Magneti Marelli right in the crucial period between the arrival of the announcement in Italy and the actual delivery of the prize in Stockholm. This episode is reported ${ }^{19}$ by a ratio of a fascist agent:

There had been invited all the city authorities, from the Duke of Bergamo to the prefect, secretary general, Fascist chiefs, mayor, superintendent, etc. It seems that at the last moment, with the exception of the Duke of Bergamo, none of those authorities, and especially the political ones, wanted to intervene. It is said that the cause is due to the fact that the awarded person, married to a Jew, repeatedly expressed his disapproval of the anti-Jewish campaign, declaring himself happy to have a Jew woman as a companion.

Driven by Nazi-like racial laws, the Fascist Italy pushed therefore Enrico Fermi to implement in the United States the invention that he had already prepared in Italy at a very concrete and detailed level.

\section{CONCLUSION}

The European Union has endured something longer than the League of Nations: It sounds like a sort of unequaled record to have assigned to the EU the Nobel Peace Prize for having secured sixty years without war. Why this grant arrived in this precise moment, not before and not after? It arrived immediately before it becomes too obvious that this EU fails to prevent a series of deadly economic wars between the same components, now again on an energy basis, initially for an Italian boycott of the Euratom Treaty, i.e. equality in access to energy at competitive prices against those of the rest of the world, but not competitive between the European Member States.

During the thirties of the former century, the self-decided foreclosure of access to sufficient energy, at first in Italy, then in Germany, generated warring ideologies against the nations endowed with a more advantaged access to energy (England and France). So it happens now: Italy first, then Germany, make themselves handicapped in their access to energy, breaking

\footnotetext{
${ }^{18}$ CNR was, and still is, the National Council of Researches.

${ }^{19}$ In the commemoration by G. Prinzi, cited above in note 18, between 22 and 23.
} 
the Euratom treaty and the linked European construction.

Italy attacks again first, having rejected nuclear power in a referendum already in 1987. But in fact also Germany with its Energiewende, energy transition, even more than Italy, is exasperating the cost of a frenetic conversion of energy sources to the so-called renewables, a euphemism that hides their intermittency and absolute inadequacy to become sufficient. They can surely be useful in low percentages, and may even become predominant in certain rare situations: wind turbines, placed on ranches in the Argentine pampas, far enough from each other to better benefit from the constant winds, sparing too long electricity distribution cables, indeed can be enough for their agro-pastoral needs, but not for industries or cities. Also the solar generation can grow up to discrete percentages in California and various other U.S. states, where vast deserts are adjacent to large cities. In Europe, situations so favorable do not exist, and even in the two countries mentioned above the intermittent sources are very far from really replacing nuclear power: It is psychopathological to completely refuse it.

Like Mussolini obtained its maximum popular support in 1935 when conquering un posto al sole, a place under the sun instead of the necessary energy sources, so are obtaining now their maximum supports the greens with a similar illusionary substitution. The prognosis of a major German capacity to suffer the derived sacrifices does not at all prevent a major disaster.

It is time for lawyers to start defending the Euratom Treaty as a necessary basis of the peaceful European construction.

And it is time for political psychologists to recall the wisdom of the signers of that Treaty, forged by suffering the foolish destruction of the previous peaceful organization: the unduly forgotten League of Nations, which was a precious gift from the new Continent to the old one, not well preserved by Europeans. The Euratom Treaty is also derived from another American gift: "Atoms for peace". It could be wiser by the Americans (not only the USA, but also this South-American Pope) to intervene on Europe's psychopathology not only after the world wars but, much better, before them: the right way to save their gifts when still in time. 